\title{
PENDAPATAN DAN KOMPARASI PETANI USAHATANI PADI SAWAH DENGAN MENGGUNAKAN TEKNOLOGI SISTEM TANAM JAJAR LEGOWO DAN KONVENSIONAL DI KABUPATEN KARAWANG
}

\section{INCOME AND COMPARATION OF FARMERS OF RICE SAHATANI BUSINESSES BY USING LEGOWO AND CONVENTIONAL JAJAR PLANTING SYSTEM TECHNOLOGY IN KARAWANG DISTRICT}

\author{
Ray Samwal Alfariqi*, Dini Rochdiani, Eti Suminartika \\ Pascasarjana Fakultas Pertanian, Universitas Padjadjaran \\ *E-mail: ray18001@mail.unpad.ac.id \\ (Diterima 23-02-2021; Disetujui 03-06-2021)
}

\begin{abstract}
ABSTRAK
Peningkatan produksi padi melalui perbaikan pada sisi produksi penting untuk dilaksanakan untuk mewujudkan kedaulatan, ketahanan dan swasembada pangan. Beberapa upaya pemerintah dalam meningkatkan produksi padi nasional telah dilakukan. Tujuan penelitian menganalisis komparatif pendapatan petani pada usahatani padi sawah dengan menggunakan teknologi sistem tanam jajar legowo dan konvensional di Kabupaten Karawang. Desain penelitian menggunakan pendekatan kuantitaif. Penelitian ini dilakukan di Kabupaten Karawang, sampel petani pada teknologi sistem tanam jajar legowo dan konvensional adalah 110 petani terdiri atas 50 petani yang menggunakan sistem tanam jarwo, dan 60 petani yang menggunakan sistem tanam konvensional. Analisis biaya dilakukan dengan mengelompokan biaya-biaya yang digunakan yang terdiri atas biaya tetap dan biaya variabel dan uji beda. Hasil penelitian Pendapatan petani pada usahatani padi sawah dengan sistem tanam jajar legowo dengan nilai rata-rata (Rp38.026.916,41/ha/MT) dari sistem tanam konvensional (Rp28.118.602/ha/MT). Komparasi pendapatan petani usahatani padi sawah berdasarkan analisis uji beda terdapat perbedaan antara pendapatan petani pada usahatani padi sawah yang menerapkan teknologi sistem tanam jajar legowo lebih besar dari konvensional.
\end{abstract}

Kata kunci: usahatani, jajar legowo, konvensional, sawah, pendapatan

\begin{abstract}
Increasing rice production through improvements on the production side is important to be implemented to achieve food sovereignty, resilience and self-sufficiency. Several government efforts to increase national rice production have been carried out. The research objective was to analyze the comparative income of farmers in lowland rice farming using the legowo row and conventional cropping system technology in Karawang district. The research design used a quantitative approach. This research was conducted in Karawang Regency, the sample of farmers in the legowo row and conventional cropping system technology was 110 farmers consisting of 50 farmers who used the jarwo planting system, and 60 farmers who used the conventional planting system. Cost analysis is done by grouping the costs used which consist of fixed costs and variable costs and different tests. The results of the research were farmers' income in lowland rice farming using the legowo row cropping system with an average value (Rp. 38,026,916.41/ ha / MT) from the conventional planting system (Rp. 28,118,602 / ha / MT). The comparison of lowland rice farming farmers' income based on different test analysis shows that there is a difference between the income of farmers in lowland rice farming that applies the legowo row planting system technology which is greater than conventional.
\end{abstract}

Keywords: farming, legowo row, conventional, rice field, income 


\section{PENDAHULUAN}

Badan Penelitian dan Pengembangan Pertanian (Balitbangtan) sebagai institusi yang bertanggung jawab untuk menggali dan mengembangkan inovasi teknologi pertanian telah melakukan berbagai penelitian dan pengkajian yang berperan dalam mengembangkan berbagai komoditas pertanian khususnya padi. Salah satu teknologi yang dikembangkan pada tahun 2013 guna meningkatkan produksi padi nasional adalah sistem tanam jajar legowo (Jarwo). Pada tahun 2016 pemerintah secara nasional melalui Kementerian Pertanian mengarahkan kegiatan peningkatan produksi padi melalui sistem tanam jajar legowo, untuk itu seluruh kegiatan peningkatan produktivitas (intensifikasi) diwajibkan untuk menerapkan teknologi jajar legowo (Kementan, 2019).

Penggunaan cara tanam seperti sistem tanam jajar legowo akan memberikan dampak besar terhadap kenaikan hasil padi persatuan hektar. Menurut Diratmaja (2013), biaya produksi pada sistem tanam jarwo memerlukan biaya yang tinggi, tetapi akan menghasilkan jumlah produksi yang tinggi pula. Hal itu disebabkan oleh adanya peningkatan biaya panen yang dihitung berdasarkan jumlah bawon yang dikeluarkan 1/5 kali dari hasil panen, karena jumlah gabah yang dihasilkan lebih tinggi. Perbedaan sistem tanam selain akan mempengaruhi biaya produksi, juga akan berpengaruh terhadap pendapatan usahatani padi sawah. Biaya produksi yang dikeluarkan seperti biaya benih, pupuk, pestisida, tenaga kerja, dan peralatan berpengaruh terhadap jumlah pendapatan yang diterima oleh petani dalam bentuk gabah kering yang dijual.

Kabupaten Karawang merupakan salah satu daerah di Provinsi Jawa Barat yang sebagian besar lahannya hampir 80 persen digunakan untuk pertanian padi sawah pada lahan sawah irigasi, saat ini masih merupakan salah satu lumbung padi nasional. Akan tetapi, dengan tingginya alih fungsi lahan pertanian khususnya sawah bertransformasi menjadi lahan industri, jalan tol, perumahan, langkanya regenerasi petani muda, dan alih profesi mata pencaharian mengakibatkan predikat lumbung padi nasional di wilayah Karawang lambat laun cenderung akan hilang.

Berdasarkan Peraturan Daerah Kabupaten Karawang Nomor 1 Tahun 2018 tentang Lahan Pertanian Pangan Berkelanjutan (LP2B), telah mematok luas lahan pertanian di Kabupaten 
Karawang yiatu 85 ribu hektar. Namun, dampak permasalahan dari alih fungsi lahan sangat berpengaruh terhadap penurunan produksi pertanian. Tahun 2018 dalam 2 musim tanam total produksi padi sawah di Kabupaten Karawang adalah 1.101.076,56 Ton (Dinas Pertanian Kabupaten Karawang, 2019). Produksi padi sawah di Kabupaten Karawang ini masih belum sesuai harapan.

Berdasarkan latar belakang yang telah diuraikan penting untuk diteliti mengenai analisis komparatif pendapatan petani pada usahatani padi sawah dengan menggunakan teknologi sistem tanam jajar legowo dan konvensional di Kabupaten Karawang.

\section{METODE PENELITIAN}

Penelitian ini dilakukan di Kabupaten Karawang, Provinsi Jawa Barat. Lokasi penelitian dipilih dengan pertimbangan bahwa Kabupaten Karawang merupakan sentral penghasil padi di Provinsi Jawa Barat yang melakukan kegiatan budidaya padi sawah dimana petaninya menggunakan teknologi sistem tanam jajar legowo dan konvensional. Waktu penelitian dilaksanakan selama bulan September sampai November 2020.
Desain penelitian menggunakan desain penelitian kuantitatif yang dilakukan untuk mengangkat fakta, variabel, ataupun fenomena-fenomena yang kemudian ditampilkan apa adanya pada waktu sekarang (Creswell, 2016).

Teknik pelaksanaan penelitian menggunakan teknik survey. Menurut Creswell (2016), survei yaitu satu cara yang utama untuk mengumpulkan data primer apabila data sekunder belum cukup lengkap untuk menjawab suatu pertanyaan. Pengumpulan data sekunder dari sejumlah unit atau sejumlah individu sehingga diperoleh informasi sebanyak mungkin dalam jangka waktu bersamaan melalui alat pengukur berupa wawancara secara mendalam disebut dengan teknik survey. Penelitian ini diukur berdasarkan satu atau lebih variabel dalam sampel atau populasi yang berangkat dari data yang diperoleh berdasarkan pengamatan atau observasi.

Populasi dalam penelitian ini adalah petani padi sawah di Kabupaten Karawang yang menggunakan teknologi sistem tanam jajar legowo dan sistem tanam konvensional. Jumlah populasi petani padi diambil berdasarkan pendekatan kelompok tani yang ada di Kabupaten Karawang, yaitu yang petaninya menggunakan 2 sistem tanam 
tersebut. Sampel petani pada teknologi sistem tanam jajar legowo dan konvensional adalah 110 petani terdiri atas 50 petani yang menggunakan sistem tanam jarwo, dan 60 petani yang menggunakan sistem tanam konvensional.

Analisis biaya dilakukan dengan mengelompokan biaya-biaya yang digunakan yang terdiri atas biaya tetap dan biaya variabel. Biaya penyusutan peralatan pertanian dapat dihitung dengan membagi selisih antara nilai pembelian dengan nilai sisa dari peralatan (Soekartawi, 2006). Pengukuran biaya penyusutan dapat menggunakan beberapa metode, salah satunya yaitu metode garis lurus, dimana nilai pembelian dikurangi dengan nilai sisa kemudian dibagi dengan umur ekonomis dari peralatan yang digunakan tersebut dengan formulasi di bawah ini:

Penyusutan $=\underline{\text { Nilai Beli }(R p)-\text { Nilai Sisa }(R p)}$ Umur Ekonomis (Tahun)

Formulasi untuk menghitung biaya usahatani adalah:

$\mathrm{TC}=\mathrm{FC}+\mathrm{VC}$

Keterangan:

TC : Biaya total

FC : Biaya tetap

VC : Biaya tidak tetap (Variabel)

\section{a. Analisis Penerimaan Usahatani}

Menurut Soekartawi (2006), penerimaan adalah jumlah produksi padi dalam usahatani dikali harga jual. Formulasi untuk menghitung penerimaan adalah:

$\mathrm{TR}=\mathrm{Y} . \mathrm{Py}$

Keterangan:

$\mathrm{TR}=$ Total penerimaan $(\mathrm{Rp})$

$\mathrm{Y}=$ Jumlah produksi $(\mathrm{Kg})$

Py $=$ Harga jual produk $(\mathrm{Rp} / \mathrm{Kg})$

\section{b. Analisis Pendapatan Usahatani}

Pendapatan usahatani adalah selisih antara penerimaan dan semua biaya (Soekartawi, 2006). Pendapatan usahatani terdiri atas pendapatan atas biaya tunai dan pendapatan atas biaya produksi total. Secara matematis pendapatan usaha tani dapat dituliskan sebagai berikut:

$\pi=\mathrm{TR}-\mathrm{TC}$

Dimana:

$\pi \quad=$ Pendapatan usaha tani (Rp)

$\mathrm{TR}=$ Total penerimaan $(\mathrm{Rp})$

$\mathrm{TC}=$ Biaya produksi total $(\mathrm{Rp})$

Selanjutnya, performa usahatani dinilai menggunakan $\mathrm{R} / \mathrm{C}$ dengan ketentuan sebagai berikut:

1. $\mathrm{R} / \mathrm{C}>1$ : Usahatani menguntungkan dan layak untuk diusahakan.

2. $\mathrm{R} / \mathrm{C}<1:$ Usahatani tidak menguntungkan dan tidak layak untuk diusahakan.

3. $\mathrm{R} / \mathrm{C}=1$ : Usahatani ada pada break even point. 


\section{Analisis Komparasi Pendapatan \\ Petani dengan Menggunakan Teknologi Sistem Tanam Jajar Legowo dan Konvensional}

Ada beberapa analisis yang dapat digunakan untuk mengetahui komparasi antara pendapatan petani usahatani padi dengan menggunakan teknologi sistem tanam jarwo dan konvensional, yaitu analisis Man-Whitney, Chi-Square serta T-test. Adapun alat analisis yang digunakan dalam penelitian ini ialah alat analisis T-test atau uji-t. Pengujian ini dilakukan jika variabel yang satu tidak berkaitan dengan variabel yang lain. Uji Independen sample t-test memiliki asumsi (Sugiyono, 2014):

a) Datanya terdistribusi normal;

b) Kedua kelompok data independen (bebas);

c) Variabel yang dihubungkan berbentuk numerik dan kategorik (dengan hanya 2 kelompok).

Prinsip pada pengujian Independent sample t-test adalah melihat perbedaan variasi dari kedua kelompok data (persentase komparasi pendapatan sistem jarwo atau tegel), sehingga sebelum dilakukan pengujian, terlebih dahulu harus diketahui apakah variannya sama (equal variance) atau variannya berbeda (unequal variance). Homogenitas varian diuji berdasarkan rumus:
$\mathrm{F}=\mathrm{S}_{1}^{2}$

Keterangan:

$\mathrm{F} \quad=$ Nilai $\mathrm{F}$ hitung

$\mathrm{S}_{1}^{2}=$ Nilai varian terbesar

$\mathrm{S}_{2}{ }^{2}=$ Nilai varian terkecil

Data dinyatakan memiliki varian yang sama (equal variance) bila F hitung $<$ F tabel, dan sebaliknya, varian data dinyatakan tidak sama (unequal variance) bila $\mathrm{F}$ hitung $>\mathrm{F}$ tabel. Bentuk varian kedua kelompok data berpengaruh pada nilai standar error yang akhirnya akan membedakan rumus pengujiannya. Uji t untuk varian yang sama (equal variance) menggunakan rumus polled varians :

Uji t untuk varian yang berbeda (unequal variance) menggunakan rumus separated variance :

$$
\begin{aligned}
t_{\text {hitung }}= & \frac{\bar{M}_{1}-\bar{M}_{2}}{\sqrt{\frac{\left(n_{1}-1\right) S_{1}^{2}+\left(n_{2}-1\right) S_{2}^{2}}{n_{1}+n_{2}-2}\left(\frac{1}{n_{1}}+\frac{1}{n_{2}}\right)}} \\
t_{\text {hitung }} & =\frac{\bar{M}_{1}-\bar{M}_{2}}{\sqrt{\frac{S_{1}^{2}+S_{2}^{2}}{n_{1}+n_{2}}}}
\end{aligned}
$$

Keterangan:

$\mathrm{M}_{1}=$ rata-rata persentase petani sistem tanam jajar legowo

$\mathrm{M}_{2}$ = rata-rata persentase petani sistem tanam konvensional

$\mathrm{S}_{1}=$ simpangan baku petani sitem tanam jajar legowo

$\mathrm{S}_{2}=$ simpangan baku petani sitem tanam konvensional

$\mathrm{N}_{1}=$ jumlah sampel petani sistem tanam jajar legowo

$\mathrm{N}_{2}=$ jumlah sampel petani sistem 
tanam konvensional

Langkah awal pengujian Independent sample t-test dengan cara menentukan hipotesis yang digunakan adalah hipotesis dua arah/dua sisi, yaitu: $\mathrm{M}_{1}=$ petani sistem tanam jajar legowo; $\mathrm{M}_{2}=$ petani sistem tanam konvensional.

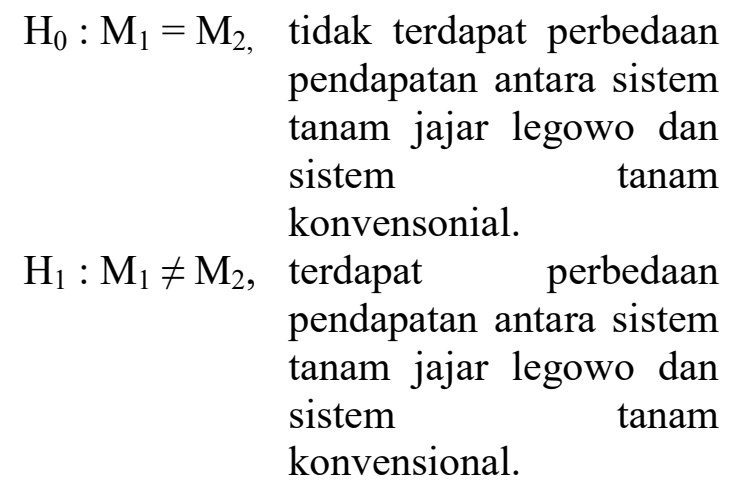

Kemudian tabel distribusi $\mathrm{t}$ dicari pada $\alpha / 2$ dengan derajat kebebasan $(\mathrm{df}=$ n-2). Pengujian dengan membandingkan nilat t-hitung dengan nilai sebaran t pada tabel:

- $t_{\text {hitung }}<-t_{\text {tabel }}$ atau $t_{\text {hitung }}>t_{\text {tabel }}$ pada taraf nyata $\alpha$, maka tolak $\mathrm{H}_{0}$

- $\mathrm{t}_{\text {tabel }}<\mathrm{t}_{\text {hitung }}<\mathrm{t}_{\text {tabel }}$ pada taraf nyata $\alpha$, maka terima $\mathrm{H}_{0}$

Kriteria pengujian dapat juga ditentukan berdasarkan probabilitas, yaitu:

- $\mathrm{H}_{0}$ diterima jika $\mathrm{P}$ value $>0,05$ dan $\mathrm{H}_{0}$ ditolak jika P value $<0,05$

\section{HASIL DAN PEMBAHASAN}

\section{Analisis Biaya}

Dalam usahatani padi sawah sistem tanam jajar legowo dan konvensional diperlukan biaya-biaya untuk membeli faktor produksi, yaitu pembelian bibit, sarana produksi (pupuk, pestisida, nutrisi dll), tenaga kerja, yang digunakan untuk kegiatan usahatani padi. Biaya yang dikeluarkan oleh petani dinyatakan dalam bentuk uang yang diperlukan untuk menghasilkan sesuatu produk dalam suatu periode produksi. Biaya usahatani padi sawah terdiri atas biaya tetap dan biaya variabel. Biaya tetap merupakan biaya yang besar kecilnya tidak dipengaruhi oleh besar kecilnya produksi sedangkan untuk biaya variabel adalah biaya yang besar kecilnya dipengaruhi oleh besar kecilnya produksi dan sifatnya habis dalam satu kali proses produksi. Rata-rata biaya usahatani dengan teknologi sistem tanam jajar legowo dan konvensioanal dapat dilihat pada Tabel 1.

Berdasarkan Tabel 1, rata-rata setiap petani mengeluarkan biaya usahatani dengan teknologi sistem tanam jajar legowo lebih besar (Rp14.894.569,per hektar per musim tanam) dari petani yang menggunakan sistem tanam konvensional (Rp12.188.598,- per hektar per musim tanam). Biaya yang paling 
banyak digunakan dalam usahatani padi sawah pada kedua sistem tanam tersebut yaitu biaya variabel.

Tabel 1. Rata-rata Biaya Usahatani Padi Sawah dengan Teknologi Sistem Tanam Jajar Legowo dan Konvensional per hektar / per petani / per musim tanam di Kabupaten Karawang

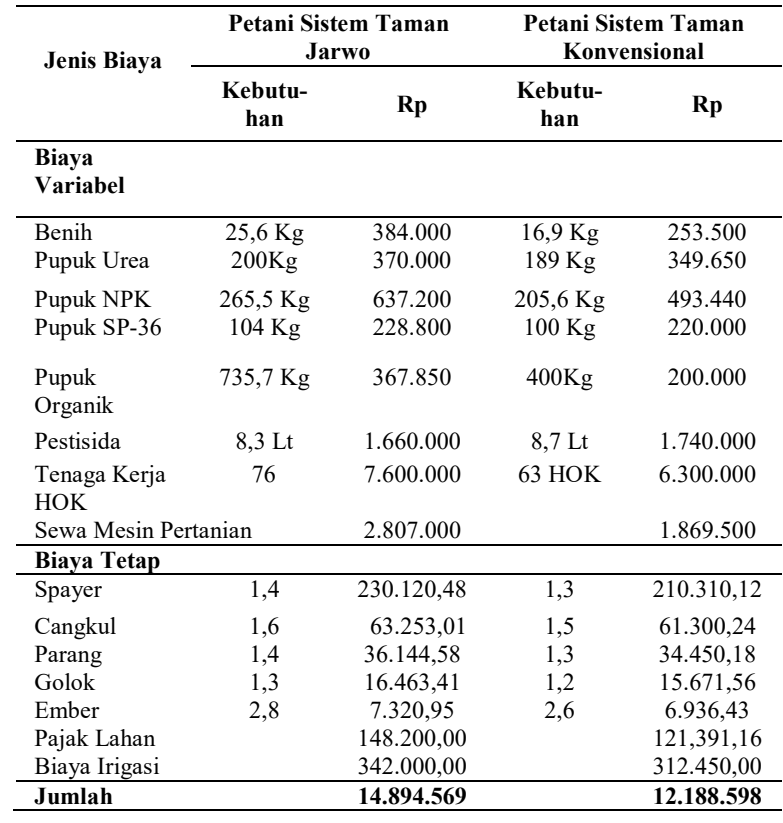

\section{a. Biaya Variabel}

Biaya variabel terdiri atas bibit, pupuk kimia (Urea, Npk Phonska, SP36), pupuk organik, pestisida, dan tenaga kerja.

\section{Benih}

Rata-rata penggunaan benih pada usahatani padi sistem tanam jajar legowo lebih besar $(25,6 \mathrm{Kg} /$ hektar/per musim tanam) dari sistem tanam konvensional (16,9 $\mathrm{Kg} /$ hektar/per musim tanam). Petani padi dengan sistem tanam jajar legowo sebagian besar menggunakan benih varietas unggul baru (VUB) berjenis Inpari dan Ciherang. Varietas benih padi yang banyak digunakan oleh petani sistem tanam konvensional adalah benih jenis Ciherang atau mekongga, namun ada juga petani yang menggunakan benih varietas Situbagendit.

Penggunaan benih unggul sangat disarankan agar kualitas dan kuantitas produksi padi dapat meningkat. Hal ini seperti hasil penelitian yang telah dilakukan oleh Arnanda et al (2016) yang melakukan penelitian mengenai tingkat efisiensi teknis padi di Kecamatan Kuala Kampar Kabupaten Pelalawan yang menyatakan bahwa penggunaan benih unggul ternyata berpengaruh secara positif dan signifikan terhadap jumlah produksi padi pada taraf nyata lima persen. Hasil penelitian ini juga menunjukkan bahwa petani dengan sistem tanam jajar legowo yang menggunakan benih bersertifikat memiliki produktivitas dan tingkat efisiensi teknis yang lebih tinggi jika dibandingkan dengan petani dengan sistem tanam konvensional yang masih menggunakan benih lokal yang belum bersertifikat.

Sejalan dengan penelitian Sembiring dalam Abdulrachman et al (2013), cara sistem tanam jajar legowo 
dengan jarak tanam yang sama mempunyai populasi tanaman lebih banyak 20 persen -60 persen sehingga penggunaan benih akan meningkat dibanding cara tanam konvensional, dan hasil gabah diperkirakan akan lebih banyak pula. bahwa dengan adanya pola seperti yang ada pada sistem tanam jajar legowo akan meningkatkan produktivitas 10 persen sampai dengan 15 persen dibandingkan dengan sistem tanam konvensional.

$$
\text { Petani padi sistem tanam }
$$
konvensional masih banyak yang menggunakan benih padi milik sendiri yang dihasilkan dari sisa panen pada musim tanam sebelumnya. Padahal anjuran dari petugas penyuluh adalah menggunakan benih varietas unggul baru atau benih bersertifikat. Masih banyaknya petani yang menggunakan benih milik sendiri ini dikarenakan benih yang bersertifikat memiliki harga yang cukup mahal. Ada juga petani yang membeli benih dari petani lain. Hal ini karena harga benih lebih murah jika dibandingkan dengan benih yang bersertifikat yang beli di toko. Padahal varietas benih yang digunakan oleh petani sangat berpengaruh terhadap produksi padi yang akan dihasilkan. Rata-rata harga benih unggul baru atau benih yang bersertifikat adalah Rp15.000 per kg. Sedangkan benih yang didapatkan dari sesama petani berkisar Rp 5.000 Rp 7.000 per kg.

\section{Pupuk (Kimia dan Organik)}

Rata-rata penggunaan pupuk kimia dan pupuk organik yang diguankan dalam usahatani padi di lokasi penelitian terdiri atas pupuk Urea, NPK Phonska, SP36 dan Petroganik. Total penggunaan pupuk kimia pada usahatani padi dengan teknologi sistem tanam jajar legowo sebesar 569,5 Kg/Hektar (Urea $200 \mathrm{Kg}$, NPK Phonska 265,5 Kg, dan SP-36 104 $\mathrm{Kg}$ ) dan pupuk organik $735,7 \mathrm{Kg} /$ Hektar. Sedangkan pada sistem tanam konvensional sebesar 494,6 Kg/Hektar (Urea $189 \mathrm{Kg}$, NPK Phonska 205,6 Kg, dan SP-36 $100 \mathrm{Kg}$ ) dan $400 \mathrm{Kg} /$ Hektar.

Dosis pemupukan yang dianjurkan oleh petugas penyuluh pertanian untuk penggunaan pupuk kimia dan organik dalam berusahatani padi adalah Urea 200 kg/ha, NPK Phonska $300 \mathrm{~kg} / \mathrm{ha}$, SP-36 $100 \mathrm{~kg} / \mathrm{ha}$ dan Pupuk organik 500$1000 \mathrm{Kg} / \mathrm{ha}$.

Berdasarkan dosis yang dianjurkan tersebut dapat dilihat bahwa pada petani kedua sistem tanam terebut di lokasi penelitian penggunaan pupuk kimia maupun pupuk organik belum sepenuhnya mengikuti dosis anjuran, 
pemakaian pupuk kimia dan organik yang berimbang akan berdampak terhadap kenaikan produksi padi dan menstabilkan hara dalam tanah. Para petani biasanya memperoleh pupuk dari kelompok tani. Namun ketersediaan pupuk di kelompok tani tidak selalu ada sehingga petani juga membeli pupuk di toko sarana tani yang ada di sekitar desa. Kelompok tani memberikan sistem pinjaman bagi petani yang membeli pupuk, benih maupun obat-obatan lain yang dapat dibayar ketika padi petani sudah panen. Hal ini sangat memudahkan dan membantu petani dalam menjalankan usahatani padinya.

\section{Pestisida}

Rata-rata penggunaan pestisida yang digunakan petani dalam memelihara padinya agar terhindar dari hama dan penyakit berbentuk padat dan cair. Jenis pestisida ini sangat bermacam-macam seperti Furadan, Bentan, Joker, Trimmer, Amistartop, gretta, dan masih banyak yang lainnya. Total penggunaan pestisida pada usahatani dengan menggunakan teknologi sistem tanam jajar legowo adalah sebesar 8,3 liter/hektar dan sistem tanam konvensional adalah sebesar 8,7 liter/hektar. Penggunaan pestisida antara petani padi jajar legowo tidak jauh berbeda dengan penggunaan pestisida pada petani padi dengan sistem tanam konvensional semua tergantung ambang batas serangan hama dan penyakit.

\section{Tenaga kerja}

Biaya yang terbesar adalah dalam penggunaan tenaga kerja. Pada usahatani padi sawah dengan teknologi sistem tanam jajar legowo lebih besar (Rp7.600.000,- per hektar/per petani/per musim tanam) dari sistem tanam konvensional (Rp6.300.000,- per hektar/per petani/per musim tanam). Rata-rata total penggunaan tenaga kerja pada usahatani padi sistem tanam jajar legowo adalah sebesar $76 \mathrm{HOK}$ per hektar dan pada usahatani padi konvensional adalah sebesar 63 HOK per hektar. Upah harian yang diterapkan pada lokasi penelitian adalah berkisar $\mathrm{Rp}$ 80.000 hingga Rp 100.000 per hari atau delapan jam kerja untuk tenaga kerja laki-laki, dan Rp 64.000 hingga $\mathrm{Rp}$ 80.000 per hari atau delapan jam kerja untuk tenaga kerja perempuan.

Tenaga kerja dalam penelitian ini terdiri atas tenaga manusia dan tenaga kerja mesin. Tenaga kerja manusia terdiri atas tenaga kerja dalam keluarga dan tenaga kerja luar keluarga. Tenaga kerja mesin dihitung dari curahan penggunaan mesin yang digunakan dalam usahatani padi. Mesin yang digunakan dalam 
usahatani padi seperti traktor pada saat proses pengolahan lahan, Jarwo transplanter untuk pindah tanam dan Combine Harvester sebagai alat untuk memanen padi. Hal ini dikarenakan kegiatan-kegiatan yang dilakukan dalam usahatani padi memang sebagian besar membutuhkan tenaga kerja yang cukup banyak dan tidak bisa dikerjakan seorang diri seperti pengolahan lahan, penanaman, penyemprotan, pemeliharaan serta proses panen, apalagi jika lahan yang dimilik oleh petani sangat luas. Para petani biasanya melakukan sendiri kegiatan usahatani padinya pada saat proses pemupukan, penyemprotan pestisida, pemberian obat-obatan, dan penyiangan lahan. Sejalan dengan penelitian Permata et al (2017), menunjukkan bahwa persentase biaya terbesar yang dikeluarkan oleh usahatani padi baik jajar legowo maupun konvensional adalah biaya tenaga kerja.

\section{b. Biaya tetap}

Biaya penyusutan alat diperhitungkan dari nilai harga peralatan dan nilai ekonomis seperti cangkul, sprayer, parang, golok, ember, biaya pajak PBB, biaya pengadaan air dan biaya sewa peralatan pertanian.

\section{Analisis Penerimaan}

Penerimaan merupakan refleksi dari kinerja produksi dan dinamika harga, artinya besarnya penerimaan ditentukan oleh dua aspek yaitu aspek produksi dan aspek harga, dengan kata lain penerimaan bisa meningkat apabila produksi meningkat walaupun harga tetap, atau harga meningkat dan produksi tetap atau kedua aspek tersebut meningkat. Harga sangat ditentukan oleh berbagai faktor, antara lain kualitas padi yang dihasilkan, tujuan penjualan dan ketersediaan gabah di pasar. Kelemahan mekanisme harga produk pertanian adalah harga yang jatuh saat panen raya, karena supply terlalu banyak. Rata-rata harga gabah di tingkat petani sebesar Rp4.000-Rp5.300/Kg. Perbedaan harga tersebut terjadi karena kualitas gabah di lokasi penelitian tergantung dari kadar air nya, jika kondisi fiik gabah kering harga akan tinggi dan sebaliknya jika kondisi fisik gabah basah harga akan rendah. Beberapa faktor yang membuat harga gabah anjlok biasanya terjadi karena pemanenan di musim hujan sehingga membuat keadaan gabah basah, dan sebelum mencapai waktu panen tanaman padi terlebih dahulu sudah rebah atau ayeuh sehingga padi membusuk dan berwarna kehitaman menyebabkan harga gabah murah. 
Pada satu musim tanam, produksi padi bisa mencapai 6-12 ton GKP/hektar dengan tingkat harga yang bervariasi tergantung pada kondisi pasar dan kulaitas hasil. Untuk lebih jelasnya hasil penerimaan hasil usahatani padi sawah dengan teknologi sistem tanam jajar legowo dan konvensional disajikan pada Tabel 2.

Tabel 2. Rata-rata Penerimaan Usahatani Padi Sawah dengan Teknologi Sistem Tanam Jajar Legowo dan Konvensional per hektar/per petani/per musim tanam di Kabupaten Karawang

\begin{tabular}{lcc}
\hline \multicolumn{1}{c}{ Uraian } & $\begin{array}{c}\text { Petani Sistem } \\
\text { Taman } \\
\text { Jajar legowo }\end{array}$ & $\begin{array}{c}\text { Petani Sistem } \\
\text { Taman } \\
\text { Konvensional }\end{array}$ \\
\hline Produksi $(\mathrm{Kg})$ & $10.512,81$ & $8.139,58$ \\
Harga $(\mathrm{Rp} / \mathrm{Kg})$ & 5034,00 & $4.982,00$ \\
\hline $\begin{array}{l}\text { Penerimaan } \\
\text { (Rp) }\end{array}$ & $\mathbf{5 2 . 9 2 1 . 4 8 5}$ & $\mathbf{4 0 . 3 0 7 . 2 0 0 , 2}$ \\
\hline
\end{tabular}

Berdasarkan Tabel 2, rata-rata penerimaan petani pada usahatani padi sawah teknologi sistem tanam jajar legowo lebih besar (Rp52.921.485,-- per hektar per musim tanam) dari sistem tanam konvensional (Rp40.307.200,- per hektar per musim tanam). Perbedaan penerimaan disebabkan oleh jumlah produksi usahatani padi sawah dengan teknologi sistem tanam jajar legowo lebih besar dibandingkan dengan usahatani sistem tanam konvensional.

Produksi padi tertinggi dalam beberapa tahun terakhir sehingga hasil panen melimpah terjadi di 2019 Musim tanam 2 dan di 2020 Musim tanam 1, hal itu meliputi faktor genetik, faktor lingkungan, serta interaksi faktor genetik dengan lingkungan. Ini berkaitan dengan curah hujan, intensitas cahaya, temperatur dan kelembaban yang sangat menentukan pertumbuhan tanaman terutama fase generatif yang dibutuhkan untuk akumulasi fotosintat optimal pada proses pengisian bulir gabah. Selain efek fisiologis yang kondusif terhadap pertumbuhan dan hasil tanaman, kondisi di atas secara tidak langsung juga dapat mengurangi perkembangan populasi hama dan penyakit tanaman di lapang. Ketujuh keajaiban solar energi itu di antaranya tanaman yang bebas hama, proses penyerbukan sempurna sehingga padi berisi, proses asimilasi fotosintesis yang sukses sehingga mencegah munculnya parasit, terjadi efesiensi pemupukan yang meningkat empat kali lipat, saat matahari bersinar menyebabkan proses pengeringan gabah menjadi cepat tidak ada gabah yang busuk, kualitas gabah yang dihasilkan adalah kualitas premium, sehingga harga jual di sawah di atas Rp.4000 (Dinas Pertanian Kabupten Karawang, 2020).

\section{Analisis Pendapatan}

Analisis pendapatan usahatani diperoleh dari selisih antara penerimaan 
dengan seluruh biaya faktor produksi yang digunakan. Jadi pendapatan usahatani padi bergantung kepada jumlah produksi padi yang dihasilkan oleh petani, harga yang diterima oleh petani, dan biaya-biaya yang dikeluarkan oleh petani untuk membeli faktor produksi yang digunakan dalam usahataninya. Menurut Santika (1999), setiap akan melakukan kegiatan usahatani, petani tentunya akan selalu berpikir apakah usahanya menguntungkan atau tidak.

Perhitungan analisis usahatani merupakan salah satu tolak ukur untuk menghitung pendapatan petani. Pada penelitian ini walaupun biaya yang dikeluarkan dalam usahatani menggunakan teknologi sistem tanam jajar legowo lebih banyak, namun pada kenyataannya jumlah pendapatan yang akan diterima oleh petani juga akan jauh lebih tinggi jika dibandingkan dengan petani padi konvensional karena dapat menghasilkan jumlah produksi yang lebih tinggi. Hasil penelitian ini juga didukung oleh beberapa penelitian lain yaitu Permata et al. (2017) dan Triatmoko et al. (2018). Kedua penelitian ini juga menunjukkan hasil yang sama yaitu usahatani padi jajar legowo memperoleh pendapatan yang lebih tinggi jika dibandingkan dengan usahatani padi konvensional. Pada penelitian Permata et al. (2017) disebutkan bahwa terdapat selisih sebesar Rp 7650066 antara pendapatan yang diterima oleh petani padi jajar legowo dan konvensional. Hal ini dikarenakan terdapat selisih produksi sebesar 1-2 ton per hektar per musim panen. Sementara itu pada penelitian Triatmoko et al (2018) diperoleh selisih sebesar Rp 8404 816,- antar pendapatan usahatani padi jajar legowo dan konvensional. Perbedaan ini terjadi karena jumlah rumpun atau populasi padi ada sistem tanam jajar legowo bertambah 37.5 hingga 45 persen sedangkan produktivitasnya bertambah dari 7 hingga 15 persen. Berikut ini analisis pendapatan usahatani padi sawah dengan teknologi sistem tanam jajar legowo dan konvensional disajikan pada Tabel 3.

Tabel 3. Rata-rata Pendapatan Petani pada Usahatani Padi Sawah dengan Teknologi Sistem Tanam Jajar Legowo dan Konvensional per hektar/per petani/per musim tanam di Kabupaten Karawang

\begin{tabular}{lcc}
\hline \multicolumn{1}{c}{ Uraian } & $\begin{array}{c}\text { Petani Sistem } \\
\text { Taman } \\
\text { Jarwo }\end{array}$ & $\begin{array}{c}\text { Petani Sistem } \\
\text { Taman } \\
\text { Konvensional }\end{array}$ \\
\hline $\begin{array}{l}\text { Biaya produksi } \\
\text { (Rp) }\end{array}$ & $\mathbf{1 4 . 8 9 4 . 5 6 9}$ & $\mathbf{1 2 . 1 8 8 . 5 9 8}$ \\
$\begin{array}{l}\text { Penerimaan } \\
\text { (Rp) }\end{array}$ & $\mathbf{5 2 . 9 2 1 . 4 8 5}$ & $\mathbf{4 0 . 3 0 7 . 2 0 0}$ \\
\hline $\begin{array}{l}\text { Pendapatan } \\
\text { (Rp) }\end{array}$ & $\mathbf{3 8 . 0 2 6 . 9 1 6}$ & $\mathbf{2 8 . 1 1 8 . 6 0 2}$ \\
\hline
\end{tabular}

Berdasarkan Tabel 3, Rata-rata pendapatan petani pada usahatani padi sawah di Kabupaten Karawang dengan menggunakan teknologi sistem tanam 
jajar legowo lebih besar (Rp38.026.916,per hektar per musim tanam) dari sistem tanaman konvensional hanya mencapai (Rp28.118.602,- per hektar per musim tanam). Selisih antara pendapatan total yang diterima oleh petani padi jajar legowo dan konvensional mencapai (Rp9.908.314,- per hektar per musim tanam). Hal ini menunjukkan bahwa teknik budidaya padi dengan teknologi sistem tanam jajar legowo memang sangat potensial dan lebih menguntungkan untuk diterapkan oleh para petani padi.

\section{Analisis Komparasi}

Analisis komparasi atau uji beda dilakukan pada pendapatan usahatani padi sawah sistem tanam jajar legowo dan konvensional, berguna untuk mengetahui perbedaan secara statistik antara total pendapatan pada usahatani padi sawah, untuk mengetahui apakah ada perbedaan rata-rata pendapatan antara usahatani padi sawah menaman sistem jajar logowo dan menananam dengan sistem konvensional digunakan analisis uji beda nilai tengah (uji t) dengan tingkat kepercayaan 95\% Djarwanto dan Subagyo (1993). Apakah ada perbedaan yang berarti (significant different), hal ini sejalan dengan pendapat
Soelistyo (2001) yang menyatakan bahwa andaikan terdapat perbedaan antara dua buah rata-rata tersebut berbeda secara kebetulan. Untuk itu, beda kedua rata-rata tersebut harus diuji lebih dahulu untuk melihat apakah beda rata-rata tersebut benar-benar signifikan, dari pendapat Djarwanto dan Subagyo (1993) dan Soelistyo (2001), maka untuk mengetahui apakah rata-rata pendapatan usahatani padi sawah sistem tanam jajar legowo lebih besar dari pendapatan usahatani padi sawah sistem konvensioal.

Hasil analisis p-value untuk perbedaan pendapatan usahatani padi sawah teknologi sistem tanam jajar legowo dan sistem tanam konvensional yaitu 0,00. Jika dibandingkan dengan taraf signifikan 5\% $(\alpha=0,05)$, maka $p$ value bernilai lebih kecil sehingga dapat disimpulkan bahwa terdapat pengaruh yang nyata antara pendapatan usahatani padi sawah yang menerapkan teknologi sistem tanam jajar legowo dan konvensional. Rata-rata terdapat perbedaan produksi usahatani padi sawah dengan menerapkan teknologi sistem tanam jajar legowo sebesar (10.512,81 $\mathrm{Kg}$ per hektar per musim tanam), sedangkan rata-rata produksi usahatani padi sawah yang menerapkan sistem tanam konvensional sebesar $(\operatorname{Rp} 8.139,58$ 
kg per hektar per musim tanam) dengan selisih $(2.373,23$ Ton/ha), sehingga mempengaruhi pendapatan, dimana pendapatan usahatani padi sawah dengan menerapkan teknologi sistem jajar legowo lebih besar $(\mathrm{Rp} 38.026 .916,41$ per hektar per musim tanam) dari pendapatan usahatani sistem tanam konvensional (Rp28.118.602,- per hektar per musim tanam).

\section{KESIMPULAN DAN SARAN}

\section{Kesimpulan}

Pendapatan usahatani padi sawah dengan sistem tanam jajar legowo dengan nilai rata-rata $(\mathrm{Rp} 38.026 .916,41 / \mathrm{ha} / \mathrm{MT})$ dan sistem tanam konvensional (Rp28.118.602/ha/MT).

Komparasi pendapatan petani usahatani padi sawah berdasarkan analisis uji beda terdapat perbedaan antara pendapatan petani pada usahatani padi sawah yang menerapkan teknologi sistem tanam jajar legowo lebih besar dari konvensional. Biaya yang dikeluarkan dalam usahatani padi teknologi sistem tanam jajar legowo lebih tinggi, jika dibandingkan dengan biaya sistem konvensional, namun rata-rata penerimaan dan pendapatan yang diterima petani usahatani padi teknologi sistem tanam jajar legowo pula lebih besar jika dibandingkan penerimaan dan pendapatan yang diterima oleh petani padi sistem tanam konvensional.

\section{Saran}

Bagi pemerintah, sebagai saran bagi pembuat kebijakan agar mengatur kelancaran distribusi sarana produksi khususnya ketersediaan pupuk dan kestabilan harga input agar berperan aktif dalam mengatur faktor-faktor di atas. Penyuluh pertanian diharapkan dapat mengedukasi para petani usahatani padi sawah teknologi sistem tanam jajar legowo sesuai dengan anjuran pemerintah, hal ini dikarenakan petugas penyuluh lapang merupakan orang yang langsung berhadapan dengan petani di lokasi pertanian, maka diharapkan adanya kerjasama yang sinergi antara petugas penyuluh lapang dengan petani, mengingat sebagian petani sistem tanam jajar legowo belum menerapkan keseluruhan komponen paket teknologi. Serta perlu adanya penyuluhan secara rutin kepada petani yang masih menggunakan sistem tanam konvensional agar mau untuk menerapkan teknologi sistem tanam jajar legowo untuk memperoleh produksi dan pendapatan yang lebih tinggi. 


\section{DAFTAR PUSTAKA}

Abdulrachman, S., N. Agustiani, L.M. Zarwazi, dan I. Syarifah. (2011). Peningkatan efisiensi penggunaan air pada padi sawah $(>20 \%)$ melalui sistem aerobik. Laporan Hasil Penelitian. Balai Besar Penelitian Tanaman Padi. (unpublished).

Ananda, R., Hadi, S., Yulida, R. (2016). Efisiendi Produksi Padi di Kecamatan Kuala Kampar Pelalawan. Jurnal SOROT, Volume 11, Nomor 2.

Creswell, J. W. (2016). Research Design Pendekatan Kualitatif, Kuantitatif, dan Mixed. Yogyakarta: Pustaka Belaja

Diratmaja A, Surdianto Y, Haryati Y. (2013). Keragaan Teknologi Cara Tanam Padi Sistem Legowo Dalam Mendukung Sistem Usahatani Terpadu di Kabupaten Sukabumi. Jurnal. J.Sains \& Teknologi Vol 10.

Djarwanto PS, Subagyo, P. (1993). Statistik Induktif, BPFE Yogyakarta.
[Kementan] Direktorat Jenderal Tanaman Pangan Kementerian Pertanian. (2019). Petunjuk Teknis Teknologi Tanam Jajar Legowo Tahun 2019. [internet]. [diunduh2020Februari29].Tersedia pada:http://tanamanpangan.pertania n.go.id/assets/front/uploads/docume nt/Petunjuk20 teknis20Jarwo20Oke.pdf

Pertama, A, L., Widjaya, S., Soelaiman, A.(2017). Analisis Perbandingan Usahatani Padi Sistem Tanam Jajar Legowo dengan Sistem Tegel di Kecamatan Seputih. JIIA, Volume 5, No. 1.

Soekartawi. (2006). Analisis Usahatani. Jakarta. Universtas Indonesia.

Sugiono. (2014). Metode Penelitian Bisnis. Bandung: CV. Alfabeta.

Triatmoko, E., Fitriadi, S., Refiana, F., Pohan, S.(2018). Perbedaan Usahatani Padi Sistem Jajar Legowo dengan Sistem Tegel di Desa Tampak Sarinah Kabupaten Tanah Laut. Jurnal ZIRAA'AH. Volume 43, Nomor 2. Halaman 149-156. 